\title{
Stilbene glycosides are natural product inhibitors of FGF-2-induced angiogenesis
}

\author{
Sajjad Hussain ${ }^{1}$, Mark Slevin ${ }^{2}$, Nessar Ahmed ${ }^{2}$, David West ${ }^{3}$, \\ Muhammad Iqbal Choudhary", Humera Naz ${ }^{4}$ and John Gaffney*2
}

Address: ${ }^{1}$ Department of Paediatrics and Adolescent Medicine, Mayo Clinic, Rochester, MN 55902, USA, ${ }^{2}$ School of Chemistry, Biology and Health Sciences, Manchester Metropolitan University, Chester St, Manchester, M1 5GD, UK, ${ }^{3}$ School of Biological Sciences, University of Liverpool, Liverpool, L69 7ZB, UK and ${ }^{4} \mathrm{HEJ}$ Research Institute of Chemistry, International Centre for Biological and Chemical Sciences, University of Karachi, Karachi 75720, Pakistan

Email: Sajjad Hussain - shussain@gmail.com; Mark Slevin - m.a.slevin@mmu.ac.uk; Nessar Ahmed - n.ahmed@mmu.ac.uk; David West - westie@liv.ac.uk; Muhammad Iqbal Choudhary - hej@cyber.net.pk; Humera Naz - hej@cyber.net.pk;

John Gaffney* - j.gaffney@mmu.ac.uk

* Corresponding author

Published: 23 April 2009

BMC Cell Biology 2009, 10:30 doi:10.1186/147|-2/21-10-30
Received: 12 October 2008

Accepted: 23 April 2009

This article is available from: http://www.biomedcentral.com/I47I-2I $21 / 10 / 30$

(C) 2009 Hussain et al; licensee BioMed Central Ltd.

This is an Open Access article distributed under the terms of the Creative Commons Attribution License (http://creativecommons.org/licenses/by/2.0), which permits unrestricted use, distribution, and reproduction in any medium, provided the original work is properly cited.

\begin{abstract}
Background: Angiogenesis, the growth of new blood vessels from the pre-existing vasculature is associated with pathological processes, in particular tumour development, and is a target for the development of new therapies. We have investigated the anti-angiogenic potential of two naturally occurring stilbene glycosides (compounds $\mathbf{I}$ and 2 ) isolated from the medicinal plant Boswellia papyriferai using large and smallvessel-derived endothelial cells. Compound I (trans-4',5'-dihydroxy-

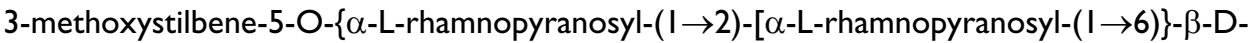

glucopyranoside was the more hydrophilic and inhibited FGF-2-induced proliferation, wound healing, invasion in Matrigel, tube formation and angiogenesis in large and small vessel-derived endothelial cells and also in the chick chorioallantoic membrane assay. Using a binding assay we were able to show compound I reduced binding of FGF-2 to fibroblast growth factor receptors-I and -2 . In all cases the concentration of compound I which caused $50 \%$ inhibition $\left(\mathrm{IC}_{50}\right)$ was determined. The effect of compound I on EGF and VEGF-induced proliferation was also investigated.
\end{abstract}

Results: Compound I inhibited all stages of FGF-2 induced angiogenesis with $I C_{50}$ values in the range $5.8 \pm 0.18-48.90 \pm 0.40 \mu \mathrm{M}$ but did not inhibit EGF or VEGF-induced angiogenesis. It also inhibited FGF-2 binding to FGF receptor-I and -2 with $\mathrm{IC}_{50}$ values of $5.37 \pm 1.04$ and $9.32 \pm 0.082$ $\mu M$ respectively and with concommotant down-regulation of phosphorylated-ERK-1/-2 expression. Compound $\mathbf{2}$ was an ineffective inhibitor of angiogenesis despite its structural homology to compound $\mathbf{I}$.

Conclusion: Compound I inhibited FGF-2 induced angiogenesis by binding to its cognate receptors and is an addition to the small number of natural product inhibitors of angiogenesis 


\section{Background}

Angiogenesis, the formation of new blood vessels from the pre-existing vasculature, is a closely regulated sequence of events beginning with the degradation of the basement membrane by activated endothelial cells (ECs). These then migrate and proliferate, form endothelial sprouts and develop capillary tubes and a new basement membrane. The key events of angiogenesis therefore involve EC proliferation, migration, tube formation and differentiation into capillaries [1]. Angiogenesis is associated with normal physiological (wound healing, endometrial cycle and embryonic development) and pathological processes (tumour growth, rheumatoid arthritis, diabetic retinopathy, and brain and cardiac infarctions) [2-4].

Angiogenesis is regulated by a balance between endogenous, soluble pro-angiogenic factors (including vascular endothelial cell growth factor (VEGF) [5], fibroblast growth factor-2 (FGF-2) [6], epidermal growth factor (EGF) and angiopoietins, and anti-angiogenic factors (including transforming growth factor- $\beta$, endostatin and thrombospondin) [7-9]. Growth factors exert their effect through binding to their cognate receptor; for example the kinase insert domain-containing receptor (VEGF) and Tie2 receptors (angiopoietins) [10]. FGFs exert their effect by binding to high affinity FGF-receptors (FGF-R) on the cell surface. In vitro, ECs express FGFR-1 and in some cases FGFR-2 but not FGFR-3 or -4 [11].

Because de-regulated angiogenesis is associated with disease progression, especially tumour development, inhibition of neo-vessel growth has become a target in drug development. Natural compounds from medicinal plants display diverse pharmacological activities and have advantages over synthetic drugs, such as smoother action, better tolerance and fewer allergic reactions [12]. For example anti-angiogenic plant derived natural products such as genistein [13], isoliquitrin [14], ginsenoside[15] and torilin [16] have potent effects on EC proliferation or tube formation.

Stilbene glycosides are natural products isolated from the medicinal plant Euphobia chiradenia and in preliminary screening were shown to be $\mathrm{PLA}_{2}$ inhibitors, have antiinflammatory properties and inhibit wound healing although the mechanism of action was not investigated [17]. Based on these results we speculated that stilbene glycosides may be anti-angiogenic and tested the efficacy of two of these compounds, trans-4',5'-dihydroxy-3methoxystilbene-5-O- $\{\alpha$-L-rhamnopyranosyl- $(1 \rightarrow 2)-[\alpha-$ L-rhamnopyranosyl- $(1 \rightarrow 6)\}$ - $\beta$-D-glucopyranoside (compound 1) and trans-4',5'-dihydroxy-3-methoxystilbene-5O-[ $\alpha$-L-rhamnopyranosyl- $(1 \rightarrow 6)]-\beta$-D-glucopyranoside

(compound 2) (Figure 1; see methods) against large and small vessel-derived EC in a range of in vitro and in vivo angiogenic assays.

\section{Results \\ Toxicity}

Compounds 1 and 2 had no significant cytotoxic effect on bovine aortic endothelial cells (BAEC) and human dermal microvascular endothelial cells (HDMEC) over the concentration range used whereas staurosporine (an inducer of active caspase- 3 and a positive control) showed significant cytotoxicity. Representative data for BAEC are shown in Figure 2.

\section{The effect of compounds I and 2 on growth factor-induced proliferation}

Compounds 1 and 2 at concentrations of 1.4-71.5 $\mu \mathrm{M}$ had no significant effect on BAEC and HDMEC growth in the absence of growth factors (Figure 3).

Over a range of concentrations compound 1 inhibited FGF-2-induced BAEC and HDMEC proliferation in a dose dependent manner with $\mathrm{IC}_{50}$ values of $48.90 \pm 0.40$ and

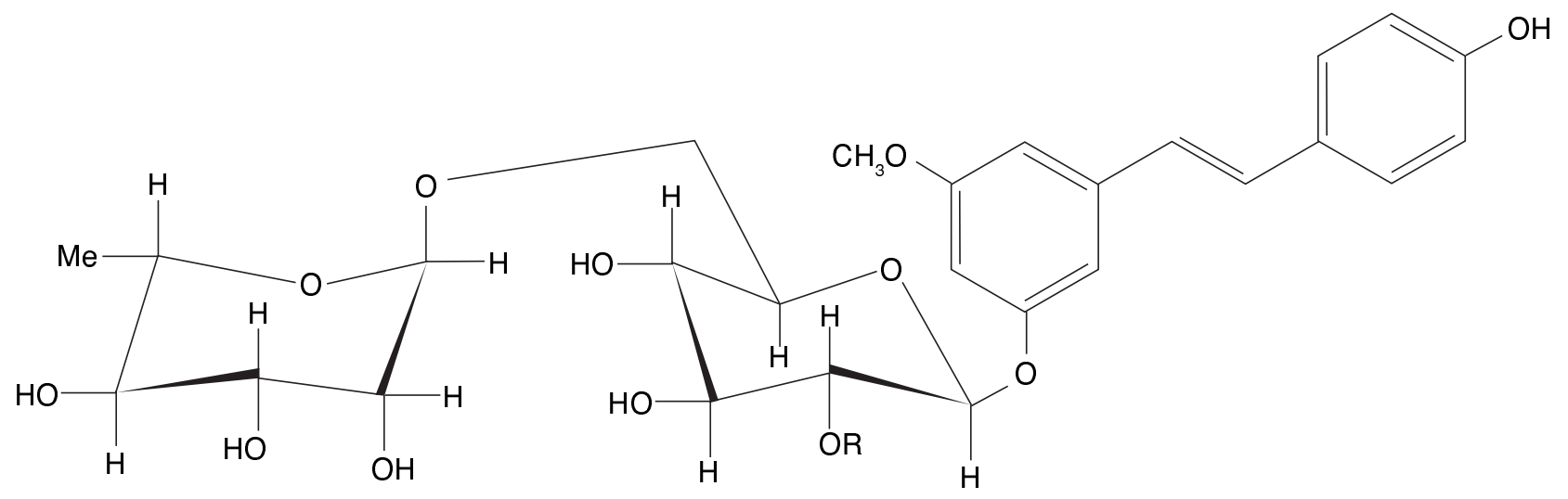

Figure I

The structures of the stilbene glycosides used in the study. Compound $\mathbf{I}(\mathrm{R}=-\mathrm{L}-\mathrm{rhamnose})$ and $\mathbf{2}(\mathrm{R}=\mathrm{H})$. 

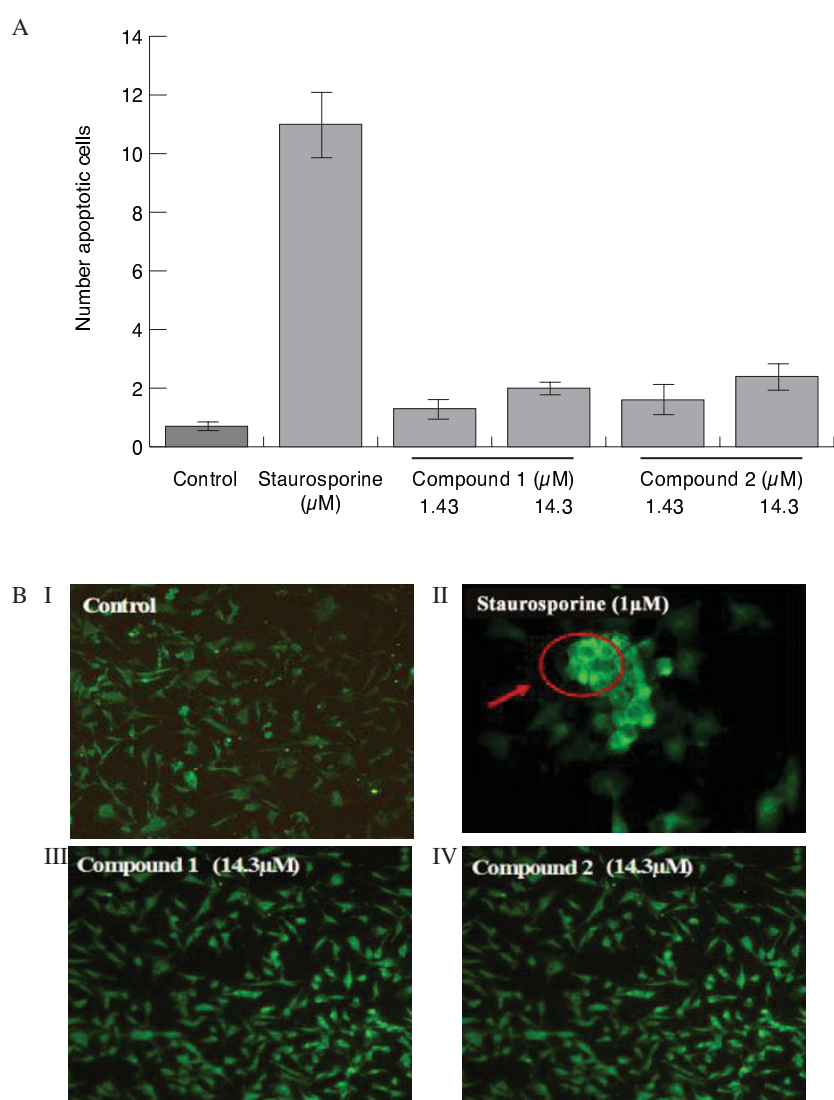

Figure 2

The effect of compounds I and 2 on BAEC viability. The cytotoxic effect was determined using (A) The MTT assay; cells $\left(7.5 \times 10^{3}\right)$ were incubated with the test compounds or with staurosporine $(\mathrm{I} .4 \mu \mathrm{M})$ an inducer of active caspase- 3 and of apoptosis for $72 \mathrm{~h}$ and MTT added. The absorbance was read at $570 \mathrm{~nm}$. (B) Active-caspase-3 apoptosis assay: cells $(4.0 \times 104 / \mathrm{ml})$ were incubated with the test compounds or with staurosporine ( $1.0 \mu \mathrm{M}, 24 \mathrm{~h})$ and stained with anti-active caspase- 3 as described below. Experiments were performed in triplicate. Representative immunofluorescence photomicrographs for BAEC were taken as described below. A group of apoptotic cells are highlighted in II.

$42.0 \pm 0.93 \mu \mathrm{M}$ respectively ( $\mathrm{p}<0.05$ in both cases). Compound 2 was a less effective inhibitor and inhibited HDMEC $\left(\mathrm{IC}_{50}\right.$ of $\left.101.0 \pm 0.50 \mu \mathrm{M} ; \mathrm{p}<0.05\right)$ but had no activity against large vessel BAEC (Table 1). The compounds had little effect on vascular endothelial growth factor (VEGF) or epidermal growth factor (EGF) stimulated proliferation (Figure 3).

\section{The effect of compounds I and 2 on endothelial cell migration during wound healing}

Two- and three-dimensional cell migration assays were used to determine whether compounds $\mathbf{1}$ and 2 had an effect on EC cell migration. In a wound healing model, cell monolayers were wounded and exposed to com-

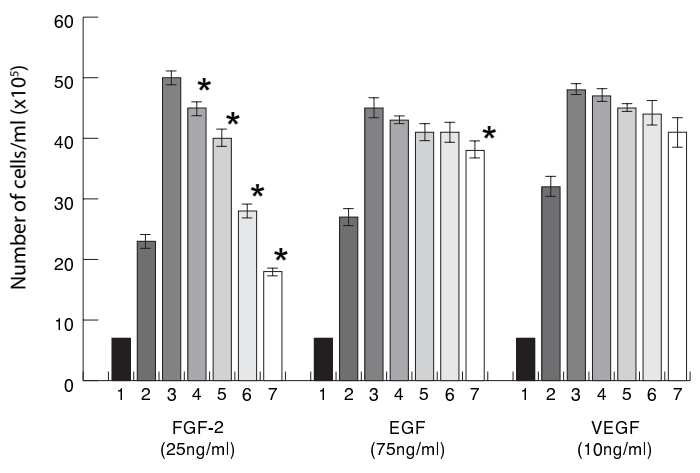

\section{Figure 3}

The effect of compound I on growth factor induced BAEC proliferation. Cells were seeded in a 6-well plate in the numbers shown and the effect of compound I on growth factor-induced proliferation $(25-75 \mathrm{ng} / \mathrm{ml})$ was determined as described below. Columns I seeded cells; 2 DMSO alone; 3 growth factor alone; 4-7 compound I at concentrations of I.43, I4.3, 28.6 and 7I.5 $\mu \mathrm{M}$. Values which differ significantly $(p<0.05)$ from growth factor alone are indicated by $*$.

Results are the mean of three experiments.

pounds 1 or 2 with and without FGF-2. FGF-2 at a final concentration of $25 \mathrm{ng} / \mathrm{ml}$ induced significant migration into the denuded area $(\mathrm{p}=0.001)$ and this was inhibited by compound 1 with an $\mathrm{IC}_{50}$ value of $41.80 \pm 0.95 \mu \mathrm{M}(\mathrm{p}$ $<0.05$; Figure 4A). Compound 2 was ineffective. Representative photomicrographs are shown (Figure 4B).

The chemotactic effect of compounds 1 and 2 was measured in the three-dimensional Boyden chamber assay. BAEC and HDMEC stimulated by FGF-2 $(25 \mathrm{ng} / \mathrm{ml})$ showed a significant increase in migration $(\mathrm{p}<0.05$ in both cases). Compound 1 inhibited migration of both cell types in a dose-dependent manner with $\mathrm{IC}_{50}$ values of $30.05 \pm 0.85$ and $21.50 \pm 0.6 \mu \mathrm{M}$ respectively $(\mathrm{p}<0.05$; Figure $4 \mathrm{C}$ ). Compound 2 was ineffective with $\mathrm{IC}_{50}$ values in excess of $800 \mu \mathrm{M}$.

\section{The effect of compounds I and 2 on endothelial tube formation}

In the presence of FGF-2 $(25 \mathrm{ng} / \mathrm{ml})$ there was an increase in BAEC and HDMEC differentiation into capillary-like structures (approximately 4.0 fold; $p=0.007$ in each case: Figure 5A). This process was inhibited by compound 1 in a dose dependent manner with $\mathrm{IC}_{50}$ values of $11.12 \pm 0.28$ and $5.8 \pm 0.18 \mu \mathrm{M}$ ( $\mathrm{p}<0.05$ in both cases) for BAEC and HDMEC respectively. Figure 5 shows representative results for BAEC. Compound 2 had no inhibitory activity.

The effect of compounds $\mathbf{1}$ and 2 on the regression of established tubular networks formed from BAEC was also investigated. Compound 1 had an $\mathrm{IC}_{50}$ value of $40.0 \pm 0.2$ 
Table I: A summary of the anti-angiogenic properties of stilbene glycosides.

\begin{tabular}{|c|c|c|c|c|}
\hline \multirow[t]{2}{*}{ Assay } & \multicolumn{2}{|c|}{ Compound I } & \multicolumn{2}{|c|}{ Compound 2} \\
\hline & BAEC & HDMEC & BAEC & HDMEC \\
\hline Proliferation in $15 \%$ FBS & NS & NS & NS & NS \\
\hline EGF-induced proliferation & NS & NS & NS & NS \\
\hline VEGF-induced proliferation & NS & NS & NS & NS \\
\hline FGF-2-induced proliferation & $48.90 \pm 0.40$ & $42.0 \pm 0.93$ & NS & $101.0 \pm 0.50$ \\
\hline FGF-2-induced migration & $41.8 \pm 0.95$ & ND & NS & ND \\
\hline FGF-2-induced chemotaxis & $30.05 \pm 0.85$ & $21.50 \pm 0.6$ & $800.0 \pm 2.78$ & $953.1 \pm 3.50$ \\
\hline FGF-2-induced tube formation & $18.20 \pm 0.65$ & $12.4 \pm 0.85$ & NS & NS \\
\hline FGF-2 invasion in matrigel & $11.12 \pm 0.28$ & $5.8 \pm 0.18$ & $18.90 \pm 0.50$ & $32.46 \pm 0.95$ \\
\hline Tubular regression & $40.0 \pm 0.2$ & ND & $37.42 \pm 0.63$ & ND \\
\hline Effect on binding to FGFR-I & \multicolumn{2}{|c|}{$5.37 \pm 1.04$} & \multicolumn{2}{|c|}{ NS } \\
\hline Effect on binding to FGFR-2 & \multicolumn{2}{|c|}{$9.32 \pm 0.082$} & \multicolumn{2}{|c|}{ NS } \\
\hline In vivo CAM assay & \multicolumn{2}{|c|}{$100 \%$ inhibition } & \multicolumn{2}{|c|}{$90 \%$ inhibition } \\
\hline
\end{tabular}

NS $=$ Not significant, overall inhibition is less than $50 \%$ and therefore $I C_{50}$ values cannot be calculated. $\mathrm{ND}=$ not determined

Figures are the $\mathrm{IC}_{50}$ values $\pm \mathrm{SD}(\mu \mathrm{M})$ and are the mean of at least three determinations.

and compound 2 of $37.42 \pm 0.63 \mu \mathrm{M}$ respectively $(\mathrm{p}<$ 0.05 in both cases; Figure 6 shows representative results).

\section{The effect of compounds I and 2 on endothelial invasion in Matrigel}

The effect of the test compounds on cell invasion was investigated using a Transwell Boyden chamber system coated with reconstituted growth factor-depleted Matrigel. BAEC and HDMEC treated with FGF-2 showed a 3.2 and 3.0 fold increase in migration into a second layer of Matrigel respectively ( $p=0.002)$. This process was inhibited by compound 1 with $\mathrm{IC}_{50}$ values of $11.12 \pm 0.28$ and $5.8 \pm 0.18 \mu \mathrm{M}(\mathrm{p}<0.05$ in both cases; Figure 7A) and compound 2 with $\mathrm{IC}_{50}$ values of $18.90 \pm 0.50$ and $32.46 \pm$ $0.95 \mu \mathrm{M}(\mathrm{p}<0.05)$ for BAEC and HDMEC respectively. Representative photomicrographs for the effect of compound 1 are shown (Figure 7B).

\section{Binding studies with FGF-2 receptors}

The anti-angiogenic effect of compounds $\mathbf{1}$ and $\mathbf{2}$ may occur by either competing with FGF-2 for its receptors or by altering receptor binding. If compound 1 and 2 were added with FGF-2 to FGFR-1 or FGFR-2 no significant inhibitory effect was observed. However, if the compounds were pre-incubated with FGF-2 a significant reduction of FGF-2 binding for compound $1\left(\mathrm{IC}_{50}=9.32\right.$ $\pm 0.729 \mu \mathrm{M}$ for FGFR-1 and $5.37 \pm 1.04 \mu \mathrm{M}$ for FGFR-2) was observed (Figure 8). Compound 2 had no inhibitory effect and neither compounds affected binding to the VEGF receptor (results not shown).

\section{The inhibition of ERKI/2 phosphorylation by compounds I and 2}

FGF-2 induced cell proliferation, migration and differentiation is mediated through receptor binding and associ- ated intracellular signal pathways involving ERK1/2 [18]. FGF-2 addition caused a 50\% increase in ERK1/2 phosphorylation compared to the control. This was inhibited by compound 1 in a dose-dependent manner (Figure 9A and $9 \mathrm{~B}$ ). Compound 2 was ineffective.

\section{Inhibition of angiogenesis in the chick chorioallantoic membrane (CAM) assay}

Since the in vitro assays described above suggest inhibition of several steps of angiogenesis we next studied the interaction of compounds 1 and 2 with FGF-2 in an in vivo system, the CAM assay. There was no evidence of angiogenesis or inflammation with the control, methylcellulose, used for the addition of the test compounds (Figure 10i). After exposure to FGF-2 (25 ng) there was a significant increase in the formation of new blood vessels growing radially towards the stimulus (Figure 10ii) $(\mathrm{m}=$ $3, \mathrm{p}<0.001, \mathrm{n}=15)$. The determination of the degree of angiogenesis $(\mathrm{m})$ is described below in the materials and methods section. After 6 days exposure to the test compounds ( $10 \mu \mathrm{g}$ in each case) there was a $100 \%$ reduction in FGF-2-induced angiogenesis in the case of compound 1 (Figure $10 \mathrm{v} ; \mathrm{m}=0, \mathrm{p}<0.0001, \mathrm{n}=8$ ) and $90 \%$ reduction with compound 2 (Figure 10vi; $\mathrm{m}=1, \mathrm{p}=0.0186, \mathrm{n}=5$ ) with a notable inhibition in the formation of normal CAM blood vessels. The test compounds alone were not inflammatory or angiogenic (Figure 10iii and 10iv).

\section{Hydrophobicity of I and 2}

The hydrophobicity descriptor (log P; a measure of the relative hydrophobicity) for compounds 1 and 2 were -0.07 and 0.76 respectively indicating that compound $\mathbf{1}$ is approximately an order of magnitude more water soluble than 2 but both compounds are very water soluble. 
A

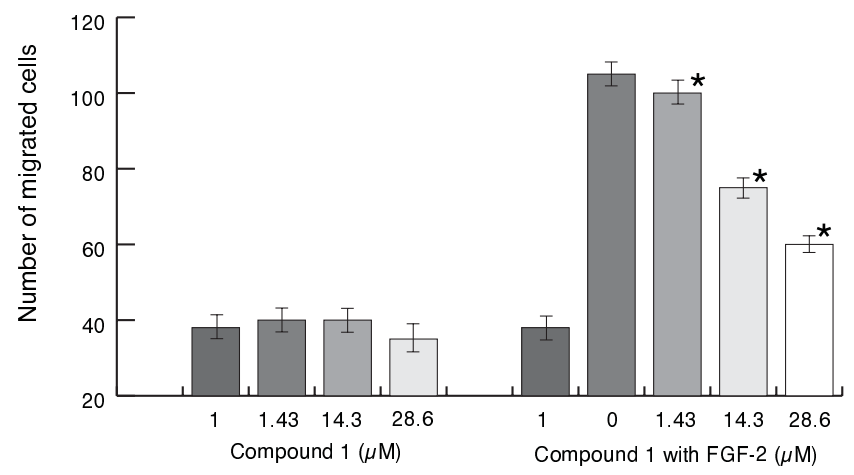

B I Time zero control
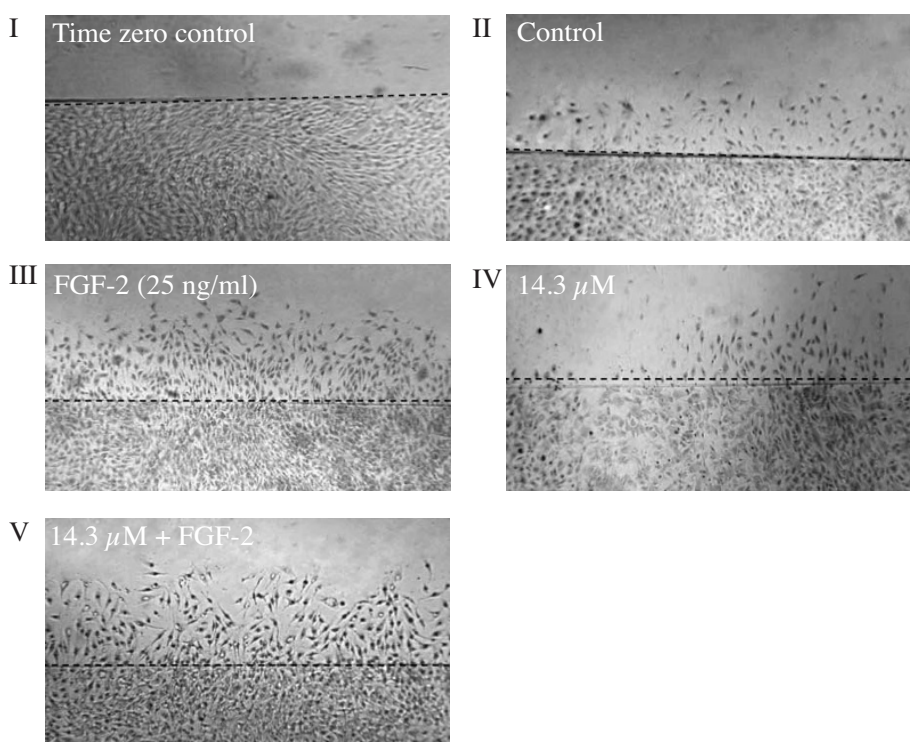

$\mathrm{C}$

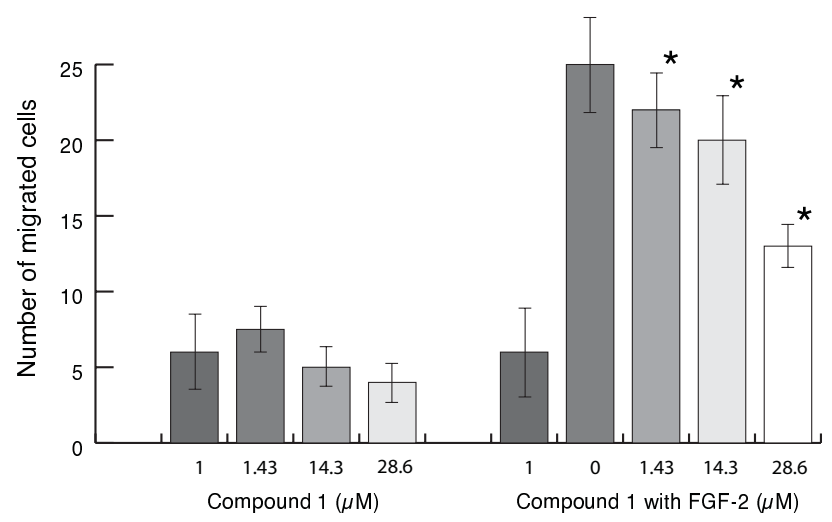

\section{Figure 4}

Effect of stilbene glycosides on FGF-2 induced BAEC migration. (A) A cell monolayer was wounded as described below and recovery was assessed in the presence of increasing concentration of the test compounds. Results are shown for compound I. Values significantly different from FGF-2 alone $(\mathrm{p}<0.05)$ are shown by *. (B) Representative photomicrographs (original magnification $\times 20$ ) show the effect of compound I on BAEC migration. DMSO was used as the control. (C) The effect compound I on FGF-2-induced cell migration in a three dimensional Boyden chamber assay. Cells were added to the upper chamber and the compound at a range of concentrations, with and without FGF-2 (25 ng/ml) added to the lower chamber (see below for method). The total number of migrated cells to the lower chamber was counted as described below. Column I, control. The results are the mean of three experiments and values significantly different from FGF- 2 alone ( $P<0.05$ ) are shown by $*$. 
A

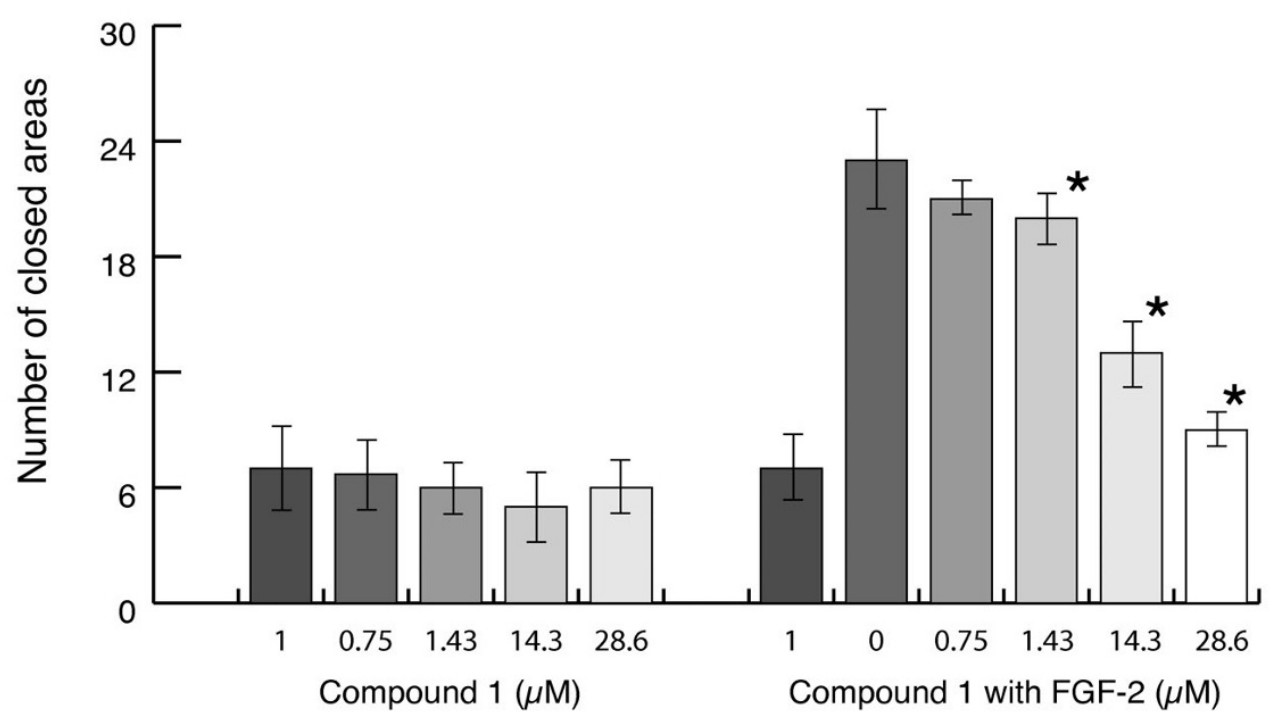

B
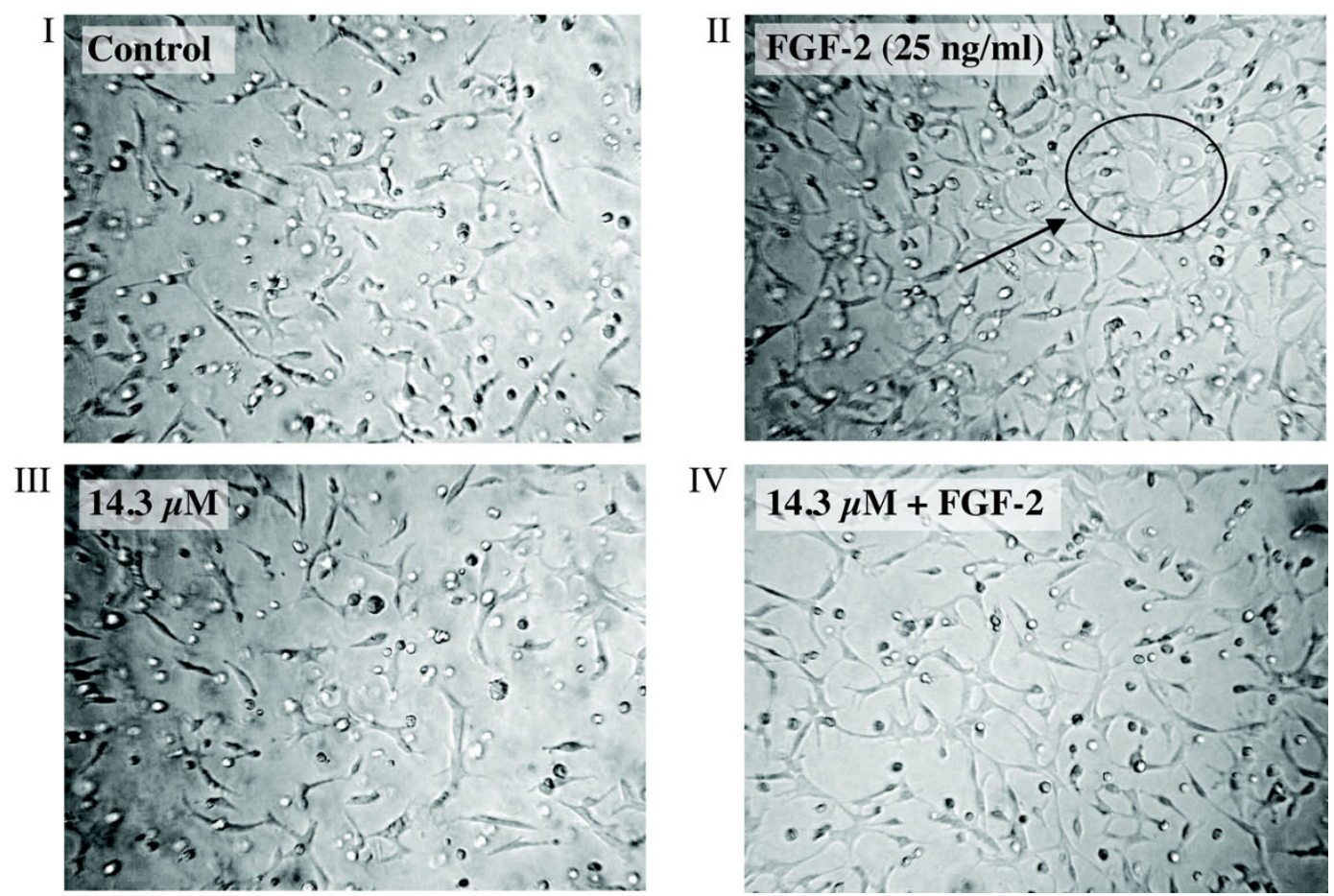

Figure 5

The effect of compound I on BAEC tube formation in Matrigel with and without FGF-2. (A) Compound I inhibited FGF-2 $(25 \mathrm{ng} / \mathrm{ml})$ induced BAEC differentiation into capillary like structures: column I, control. In the absence of FGF-2 there was no inhibitory effect on tube formation. Values significantly different from FGF-2 alone $(p<0.05)$ are shown by *. Results are the mean of three experiments (B) Representative photomicrographs (original magnification $\times 20$ ) show tube formation by BAEC. In the presence of FGF-2 a closed tubular network was evident (an example is shown in II) and this was abolished by compound I (shown in IV). In the control (I0 and with compound I alone (III) there was no evidence of tube formation. 


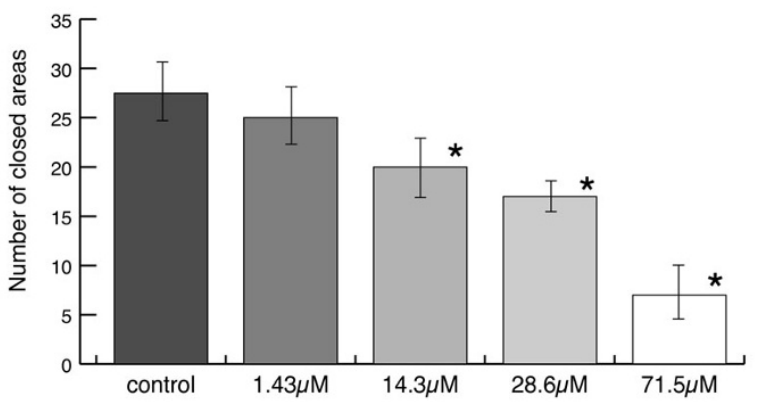

B
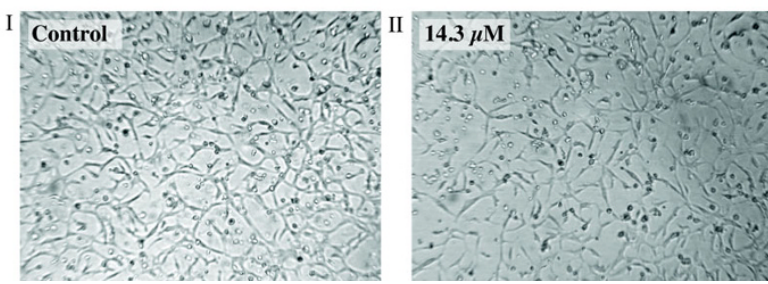

Figure 6

(A) The effect of compound I on the regression of established BAEC tubular networks. Cells were treated with FGF-2 on matrigel until an established tubular network was visible. The test compounds were added in serum and after $24 \mathrm{~h}$ the number of closed areas was counted as described below. The results are the mean of three experiments and values differing from the control are shown by*. (B) Representative photomicrographs of tubular structures shown for FGF-2 alone (control; panel I) and in the presence of compound I (panel II) show tubular regression in the presence of the test compound (original magnification $\times 20$ ).

\section{The effect of compounds I and 2 on EGF and VEGF-} induced angiogenesis

Compounds 1 or 2 had no significant inhibitory effect on EGF or VEGF-induced BAEC- or HDMEC growth or differentiation as measured in the angiogenesis assays described above (Table 1).

\section{Discussion and conclusion}

We have demonstrated the ability of compound 1, a plant-derived stilbene glycoside to inhibit multiple stages of angiogenesis in in vivo and in vitro assays with $\mathrm{IC}_{50}$ values in the range of $5.8 \pm 0.18$ to $48.90 \pm 0.40 \mu \mathrm{M}$. Compound 1 was equally effective against small and large vessel-derived ECs but compound 2 was largely ineffective. Compound 1 which contains an additional bulky Lrhamnose residue and is approximately 10 times more water soluble than compound 2 was the more effective inhibitor. Since the compounds show approximately $90 \%$ structural homology, activity appears to be inversely related to hydrophobicity. We have shown using other plant-derived natural products that increased polarity cor- relates with effectiveness of growth factor inhibition. For example, the ability of sesterterpenes to inhibit FGF-2induced angiogenesis [18] and cheiradone to inhibit VEGF [19] increased with polarity.

Stilbene glycosides and their derivatives are naturally occurring phytoalexins, widely distributed and with diverse activities. For example resveratrol, a stilbene glucoside inhibited the differentiation of human umbilical vein ECs into capillary-like structures at concentrations of 0.1-1 $\mathrm{mM}$ [20] and induced apoptosis in colon cancer cells [21]. Angiogenesis is an invasive process that requires degradation of the basement membrane, cell migration and removal of obstructing matrix proteins to allow space for the formation of the vessel lumen [22]. Matrix metalloproteinases (MMPs), in particular MMP-2 and -9 are the principal mediators of these events [23]. Stilbene glycosides are potent anti-oxidants with $\mathrm{IC}_{50}$ values in the $\mu \mathrm{M}$ range [24] and may suppress MMP expression, and therefore angiogenesis by decreasing oxidative stress, a known inducer of MMP-9. This may indirectly regulate angiogenesis [25]. However, we were able to show that the major effect of compound 1 was in reducing FGF- 2 induced angiogenesis. In the absence of growth factors, stilbene glycosides had little effect on EC proliferation and migration. However, compound 1 bound to FGF-2 reducing its binding to its cognate receptors (FGFR-1 and -2) with $\mathrm{IC}_{50}$ values of 5.37 to $9.32 \mu \mathrm{M}$ respectively. The effect was specific with no inhibition of EGF or VEGF activity and compound 1 did not bind in vitro to the VEGF receptor. Angiogenesis is regulated by a balance between pro- and antiangiogenic regulators. If the pro-angiogenic stimulators predominate ECs switch to an angiogenic phenotype. It appears that stilbene glycosides regulate angiogenesis by decreasing the activity of pro-angiogenic FGF-2. In addition compounds $\mathbf{1}$ and $\mathbf{2}$ showed activity in the in vivo CAM assay. The suppression of FGF-2 induced vascular networks was accomplished without inflammation or embryo death. In vitro, compound 1 reduced the formation of vascular networks by BAECs and HUVECs on Matrigel beds and caused regression of established networks. Compound 1 also reduced FGF-2 induced proliferation and migration of ECs. It is possible therefore, that compound 1 may have a role in reducing excessive angiogenesis.

Activation of signal transduction pathways follows binding of growth factors to receptor tyrosine kinases and in the case of FGF-2 involves phosphorylation of ERK-1 and -2 , culminating in the activation of the transcription factor c-jun and initiation of the early events of angiogenesis [26]. We were able to show that compound 1 reduced levels of phospho-ERK-1 and -2 in FGF-2 stimulated ECs in a dose-response manner. 

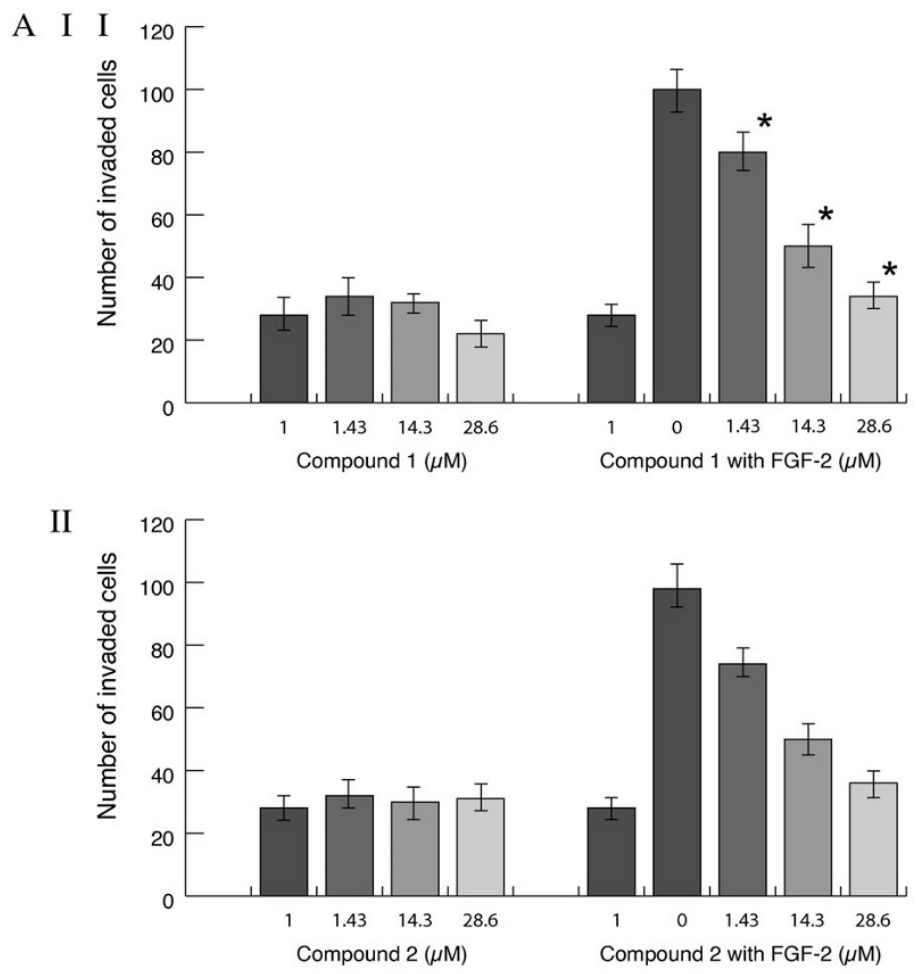

B
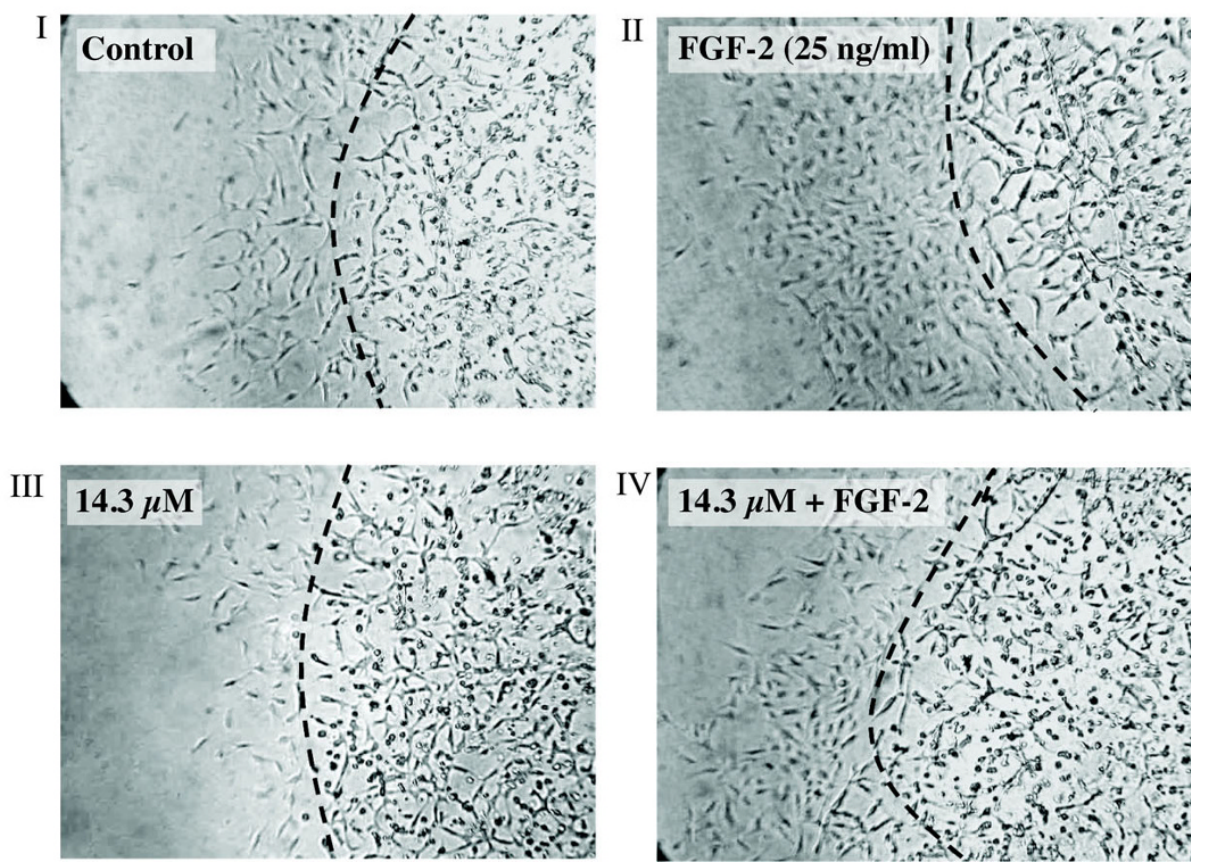

\section{Figure 7}

The effect of compounds I (AI) and 2 (AII) on BAEC invasion into a Matrigel layer was studied using the chemoinvasion assay described below. Cells $\left(1.7 \times 10^{4}\right)$ were added to the Matrigel coated upper Boyden chamber and the compounds with or without FGF-2 added to the lower chamber. Cell invasion was measured after $24 \mathrm{~h}$ and assessed as described below. Values significantly different $(p<0.05)$ from FGF-2 alone are shown by *. Results are the mean of three experiments. (B) Representative photomicrographs are shown for the effect of compound I on BAEC (original magnification $\times$ 20). Increased migration was seen with FGF-2 (25 ng/ml; panel II) and this was reduced in the presence of compound I (panel IV). 


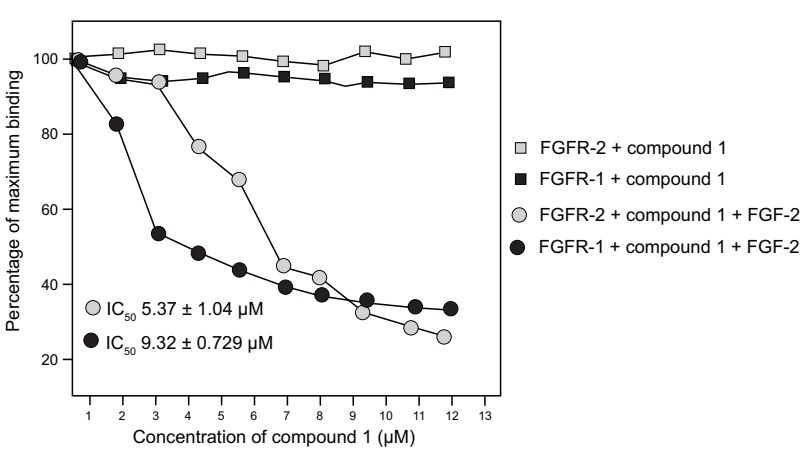

Figure 8

The effect of increasing concentrations of compound I on FGF-2 binding to FGFR-I and -2. The soluble receptor was coated onto the wells of a 96 -well plate and blocked with I\% BSA. The test compounds and growth factor were premixed for $2 \mathrm{~h}$ and added to the plate. After $2 \mathrm{~h}$ the plate was washed and incubated with antibodies to the growth factor, then peroxidase-conjugated IgG for $45 \mathrm{~min}$. Peroxidase substrate was added and the absorbance read at $405 \mathrm{~nm}$ (se below for detail).

A
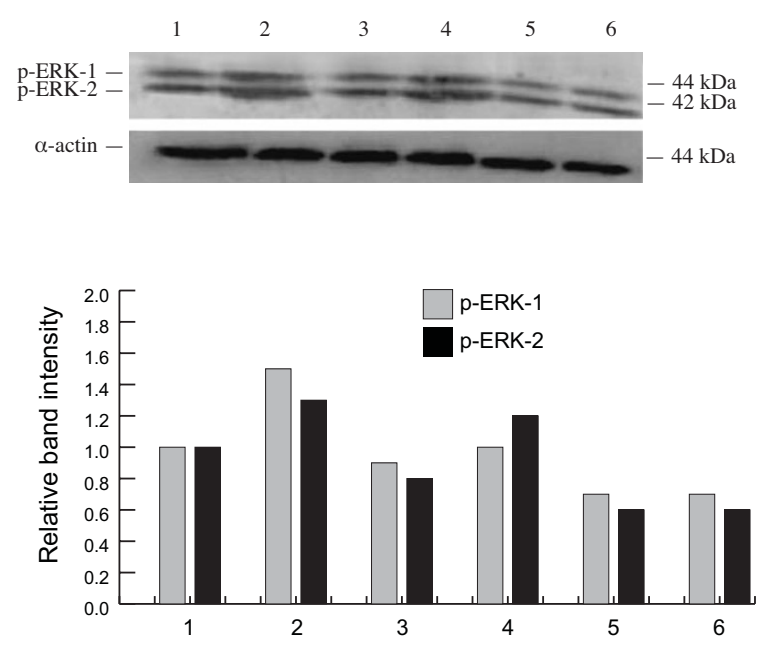

Figure 9

(A) Western blots of p-ERK-I and -2 were performed on BAEC treated with compound I as described

below. (B) The bar charts show relative protein expression compared to the control given an arbitrary value of I.0. All experiments were performed at least twice and a representative example is shown. Lane I control, lane 2 FGF-2 (25 ng/ $\mathrm{ml}$ ), lane 3 compound I ( I.43 $\mu \mathrm{M}$ ), lane 4 compound I (I4.3 $\mu \mathrm{M})+\mathrm{FGF}-2$, lane 5 compound I $(28.6 \mu \mathrm{M})$, lane 6 compound I $(28.6 \mu \mathrm{M})+$ FGF-2.
The few known natural product inhibitors of FGF-2 include two sesterterpenes, leucosesterterpene [18] and torilin [16] and the aporphine alkaloid sinomenine [27]. Both torilin and sinomenine show potential as antitumour agents, the latter is active against synovial carcinoma [27]. Since compound 1 shows anti-angiogenic activity with similar $\mathrm{IC}_{50}$ values to sinomenine there is a possibility that it may have potential as an anti-tumour agent.

\section{Methods}

Angiogenic inhibitors

Two stilbene glycosides, trans-4', 5'-dihydroxy-3-meth-

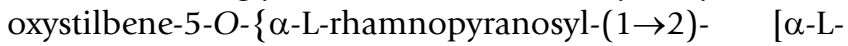
rhamnopyranosyl- $(1 \rightarrow 6)\}$ - $\beta$-D-glucopyranoside (compound 1) and trans-4',5'-dihydroxy-3-methoxystilbene-5$O$-[ $\alpha$-L-rhamnopyranosyl- $(1 \rightarrow 6)]$ - $\beta$-D-glucopyranoside (compound 2) (Figure 1) were isolated from the medicinal plant Boswellia papyriferia. Their isolation and structural and chemical characterisation is described in detail elsewhere [17].

\section{Materials}

Matrigel was obtained from Becton Dickinson, UK; FGF-2 and goat anti-active caspase- 3 antibody from R\&D Systems; VEGF ${ }_{165}$ from Apollo Cytokine Research, (Cambridge, UK), EGF, VEGFR-1 and -2, FGFR-1 and -2, antiFGF-2 and anti-VEGF antibodies were obtained from Santa Cruz Biotechnology (Heidelberg, GDR). ABTS peroxidase substrate kit (Vector, UK), Transwell chamber system, culture plates and flasks (SLS, UK), anti-goat Alexa flour 488 conjugated green fluorescence dye and other chemical of commercial grade were purchased from Sigma (Poole, UK).

\section{Cell culture}

Human dermal microvascular endothelial cells (HDMECs) and the appropriate medium were purchased from TCS Cellworks (Buckingham, UK) and were cultured and maintained according to the supplier's instructions. Bovine aortic endothelial cells (BAECs) were isolated and characterised as described previously [28]. They were routinely cultured in Dulbecco's modified Eagles medium (DMEM) in $5 \% \mathrm{CO}_{2}$ at $37^{\circ} \mathrm{C}$ containing varying concentrations of foetal calf serum (FCS) as described above. All cells were used between passages six to nine.

\section{Cell proliferation studies}

Cells were seeded in triplicate at a concentration of $6.0 \times$ $10^{5} / \mathrm{ml}$, in $2 \mathrm{ml}$ of complete medium in 6 -well plates. After attachment $(24 \mathrm{~h})$, medium was replaced with serum poor medium (SPM), containing $2.5 \%$ FCS in which the cells grew at a significantly reduced rate. 

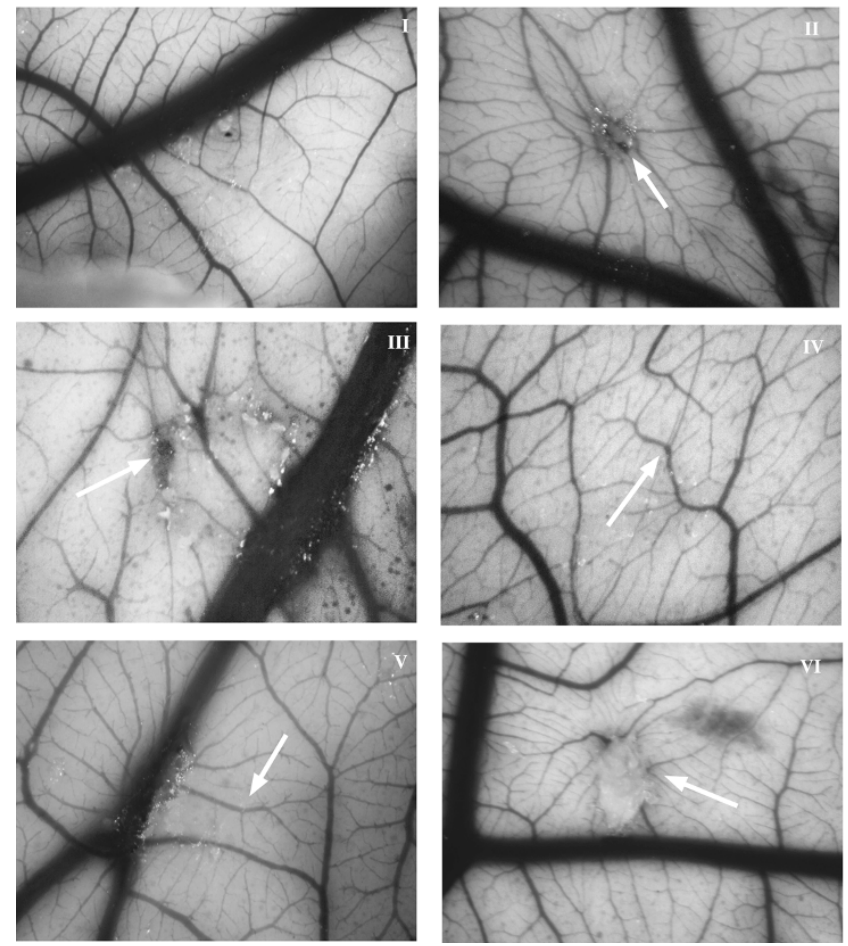

Figure 10

Compounds $I$ and 2 inhibit in vivo angiogenesis in the CAM assay (see below for method). (I) methylcellulose alone showed no evidence of angiogenesis or inflammation, (II) FGF-2 induced a network of new blood vesselsradiating from the site of application (arrow), (III) and (IV) compounds I and $\mathbf{2}(\mathrm{I} 0 \mu \mathrm{g})$ alone again showed no inflammatory or angiogenic response at the site of application. (V) and (VI) When compounds I and $\mathbf{2}(\mathrm{I} 0 \mu \mathrm{g})$ were added together with FGF-2 there was complete inhibition of blood vessel formation.

Representative photomicrographs are shown and the arrow indicates the point of application of the test compounds.

Original magnification $\times 40$.

Growth factors, FGF-2 (25 ng/ml), EGF (75 ng/ml) and VEGF (10 ng/ml) [29] and test compounds at different concentration were added and cells incubated for a further $72 \mathrm{~h}$. Control wells were treated with $5 \mu \mathrm{l}$ DMSO. Concentration ranges of test compounds and pre-incubation times were based on pilot studies. After $72 \mathrm{~h}$, cells were washed in PBS, detached in 0.05\%w/v trypsin in PBS, and counted on a Coulter counter (Coulter Electronics, Hialeah, FL) set to a threshold of $30 \mu \mathrm{m}$. Experiments were performed in triplicate and repeated at least twice.

\section{Chemotaxis assay}

The effect of compounds $\mathbf{1}$ and $\mathbf{2}$ on cell migration was examined in vitro using a modified Boyden chamber system with $8.0 \mu \mathrm{m}$ pore polycarbonate filter inserts (TSL, UK). The filter was coated overnight with $0.1 \% \mathrm{w} / \mathrm{v}$ gelatine, and air-dried. Cells $\left(1 \times 10^{5}\right)$ were placed in the upper part of the filter and test compounds at different concentrations with and without growth factors were added to the lower part in SPM. Cells were incubated at $37^{\circ} \mathrm{C}$ for $6 \mathrm{~h}$ and the filter removed and the upper side containing non migrated cells wiped and rinsed. The filters were fixed (4\% paraformaldehyde), and stained (Geimsa) and cell migration in duplicate wells was determined by counting cell numbers on the lower surface. Experiments were performed in triplicate and at least two times.

\section{Endothelial cell migration in wound healing}

Cells $\left(6 \times 10^{4} / \mathrm{ml}\right)$ were added to a Thermanox cover slip in a 24-well plate in complete medium and incubated for 24-48 h. When confluent, the medium was replaced with DMEM containing $0.1 \%$ FCS and incubated for a further 48 h. Cover slips were washed (PBS, $\times 3$ ), wounded with a sterile razor to produce a straight edged cut and washed in PBS to remove dislodged cells. Cover slips were added to a fresh 24 -well plate in $0.1 \%$ FCS and incubated with FGF-2 (or other growth factors) and a range of concentrations of test compounds for $18 \mathrm{~h}$. Under these conditions, there was negligible proliferation but measurable migration. Slides were fixed in ethanol (100\%), stained with methylene blue and photographed. For each slide, 10 fields of view $(2 \mathrm{~mm} \times 1.45 \mathrm{~mm})$ were counted at random. Each experiment was performed in triplicate and at least twice.

\section{Cell differentiation and invasion assays in Matrigel}

Cells $\left(1.0 \times 10^{6} / \mathrm{ml}\right)$ were mixed with an equal volume of Matrigel (Becton -Dickinson, Oxford, UK; prepared according to the supplier's instructions) at $4^{\circ} \mathrm{C}$. Aliquots $(80 \mu \mathrm{l})$ were added to the wells of a 48 -well plate and allowed to polymerise $(1 \mathrm{~h})$ then $500 \mu \mathrm{l}$ of $15 \%$ FCS containing FGF-2 (25 ng/ml; or other growth factors), with or without test compounds was added. The cells were incubated for $24 \mathrm{~h}$ at $37^{\circ} \mathrm{C}$ then fixed in $4 \%$ paraformaldehyde ( $5 \mathrm{~min}$ ), washed in cold ethanol and the plate air dried. Cells were stained with Geimsa (30 s), air dried and photographed. Ten random fields were selected and the number of closed tubes counted.

The procedure described above was repeated and wells having a uniform network of tubes were used to assess invasion into a second layer of Matrigel. Matrigel $(100 \mu \mathrm{l})$, with and without the test compounds was added to the cells and allowed to polymerise ( $1 \mathrm{~h}$ at $\left.37^{\circ} \mathrm{C}\right)$. FCS (15\%) was added and the cells incubated for $24-72 \mathrm{~h}$ when tube growth into the upper layer was measured as described above.

Tube regression under the influence of the test compounds was also investigated. Cell suspensions were mixed with Matrigel supplemented with FGF-2 (25 ng/ 
$\mathrm{ml})$ in $15 \%$ FCS as described above. The gel was allowed to polymerise $(1 \mathrm{~h})$ and FCS $(0.5 \mathrm{ml}$ with FGF-2, $(25 \mathrm{ng} /$ $\mathrm{ml}$ ) added and cells incubated for $24 \mathrm{~h}$. Wells which had a uniform network of tubes (assessed with a Nikon inverted microscope $)$ were treated with medium $(0.5 \mathrm{ml}$, $15 \%$ FCS) containing test compounds. Plates were incubated for $24 \mathrm{~h}$, fixed and stained as described above and tube formation counted. All experiments were performed in triplicate and at least two times.

\section{Binding assay}

Competition between growth factors, their cell surface receptors and test compounds was assessed in an ELISA assay as described by [30]. A 96-well plate was coated overnight with $2 \mu \mathrm{g} / \mathrm{ml}$ of the soluble receptors (FGFR-1 or -2 and VEGFR-1 or -2 ) and blocked with 1\% BSA in PBS containing $0.05 \%$ Tween-20. The test compound and FGF-2 or VEGF were pre-mixed for $2 \mathrm{~h}$ and added to the plate and incubated for $2 \mathrm{~h}$. The plate was washed $(\times 3$ with PBS-Tween-20) and incubated with anti-FGF-2 IgG (1:500 in PBS-Tween-20) or anti-VEGF IgG (!:250 in PBSTween-20) for $45 \mathrm{~min}$, washed and incubated with horseradish peroxidase conjugated goat anti-IgG (Santa Cruz, 1:1000) for a further $45 \mathrm{~min}$. After washing $(\times 3)$, ABTS peroxidase substrate was added and the absorbance read at $405 \mathrm{~nm}$. $\mathrm{IC}_{50}$ values were calculated from the data using the EZ-Fit enzyme kinetic software (Perella Scientific Inc., Amherst, USA).

\section{Western blotting}

The method is described in detail elsewhere [18]. In brief, cells were lysed in RIPA buffer, protein concentration determined using the Biorad assay, and approximately 20 $\mu \mathrm{g}$ aliquots separated by $12 \%$ SDS-PAGE, electroblotted onto nitrocellulose filters (Hoefer, San Francisco, Ca, USA), blocked overnight with 1\% BSA in TBS-Tween and incubated for $4 \mathrm{~h}$ at RT with characterised antibodies to phosphor-ERK1/2 (AutogenBioclear, mouse monoclonal, $1: 1000)$. $\alpha$-Actin (Sigma, UK; $1: 1000$ ) was used as a loading control. Filters were washed in TBS-Tween and stained with antibodies to peroxidase-conjugated secondary antibody. Proteins were detected with the ECL system (Amersham, UK). Protein expression was estimated spectrophotometrically from band intensity. Results are semi-quantitative and given a numerical value compared to the weakest observed band assigned an arbitrary value of 1.0. All experiments were performed at least twice and representative examples are shown.

\section{Chick chorioallantoic assay}

The angiogenic activity of test compounds was determined using the semi-quantitative chick chorioallantoic assay (CAM) as described previously [31]. To expose the CAM a window was created in the shells of 4 day-old chicken eggs. On day 8 , a $2 \mathrm{~mm}^{3}$ methycellulose pellet (5 $\mu \mathrm{l}$ of $1 \%$ sterile methylcellulose; 400 centipoise, Sigma UK) containing no additions (control), the test compound $(10 \mu \mathrm{g})$ with and without FGF-2 (100 ng) were applied to the membrane. The resultant angiogenesis scored on day 14 as 0 - negative; 0.5 - change in vessel architecture; 1 - partial spokewheel (1/3 of circumference exhibits directional angiogenesis); 2- spokewheel; 3 or greater- strong and fully spokewheel. This approach enabled calculation of an accumulated response in each group. To photograph the membrane, $2 \mathrm{~cm}^{3}$ of a $50 \%$ emulsion of aqueous paraffin oil containing 2\% Tween80 was injected at the site of application and photographed using a Leitz dissecting microscope. Each experiment was performed five times and statistical significance was determined by the Mann-Whitney U test and the data is expressed as a median value $(\mathrm{m})$.

\section{Toxicity}

Stilbene glycoside toxicity was determined using the MTT and active caspase- 3 assays. BAECs or HDMECs $(7.5 \times$ $10^{3}$ ) were seeded in a 96 well plate and incubated for $4 \mathrm{~h}$ to allow cell adhesion. The test compound or staurosporine $(1 \mu \mathrm{M})$, an inducer of active caspase- 3 and therefore of apoptosis was added to the wells. Control cells were treated with PBS and the plate was incubated at room temperature for 72 hours. MTT reagent $(10 \mu \mathrm{l})$ was added followed by incubation at room temperature for $2-$ $4 \mathrm{~h}$. When a purple precipitate was visible, detergent reagent $(100 \mu \mathrm{l})$ was added to the plates and incubated at room temperature for $2 \mathrm{~h}$ in the dark. Absorbance was measured at $570 \mathrm{~nm}$ using a microplate reader.

In the apoptosis assay, HDMECs or BAEC $\left(4 \times 10^{4} / \mathrm{ml}\right)$ in complete medium were added to the chambers slide and allowed to adhere for $24 \mathrm{~h}$. The test compound (X $\mu \mathrm{M})$ or staurosporine $(1 \mu \mathrm{M})$ were added to all wells except control (PBS) and incubated for 24 hours. Wells treated with staurosporine were immediately washed (PBS) and fixed (4\% paraformaldehyde) when cell morphology became round (2-4 h). After washing and fixing, cells were permeablized $(0.1 \%$ Triton $X-100 ; 10 \mathrm{~min})$, washed $(\times 5 \sim 5 \mathrm{~min}$ each), air dried and blocked with 1\% BSA in 1:50 TBSTween for $1 \mathrm{~h}$ at room temperature. Cells were incubated with goat anti-active caspase-3 (R\&D system, UK; 1\% BSA in TBS-Tween) for $1 \mathrm{~h}$. The plates were incubated with anti-goat Alexa-Flour 488 conjugated green fluorescent dye for $1.5 \mathrm{~h}$ at room temperature. Ten random homogeneous fields were viewed, and photographed.

\section{Determination of the hydrophobicity of I and 2}

The SdQSAR program [32] (Tripos, St Louis, Mo) was used to determine the octanol-water partition coefficient a measure of hydrophobicity. 


\section{Statistical analysis}

All data were expressed as mean \pm SEM. Statistical analysis was performed by one way analysis of variance and a value of $\mathrm{p}<0.05$ was considered statistically significant.

\section{Authors' contributions}

SH carried out the angiogenic assays. JG, MS and NA participated in the design of the study and JG prepared the manuscript. MIC and $\mathrm{HN}$ isolated and characterised the stilbene glycosides. DW performed the CAM assay. All authors read and approved the manuscript.

\section{Acknowledgements}

We would like to thank M Hoult for assistance in the preparation of the manuscript.

\section{References}

I. Folkmann J: Fundamental concepts of the angiogenic process. Curr Mol Med 2003, 3:643-65I.

2. Avouac J, Uzan G, Kahan A, Boileau C, Allanore Y: Endothelial progenitor cells and rheumatic disorders. Joint Bone Spine 2008, 75: $131-137$.

3. Slevin M, Kumar P, Gaffney J, Kumar S, Krupinski J: Can angiogenesis be exploited to improve stroke outcome? Mechanisms and therapeutic potential. Clin Sci (Lond) 2006, I I I: I7I-I83.

4. Kumaran G, Clamp AR, Jayson GC: Angiogenesis as a therapeutic target in cancer. Clin Med 2008, 8:455-458.

5. Slevin M, Kumar P, Wang Q, Kumar S, Gaffney J, Grau-Olivares M, Krupinski J: New VEGF antagonists as possible therpapeutic agents in vascular disease. Expert Opin Investig Drugs 2008, I $7:|30|-|3| 4$.

6. Cao Y, Cao R, Hedlund EM: Regulation of tumor angiogenesis and metastasis by FGF and PDGF signalling pathways. J Mol Med 2008, 86:785-789.

7. O'Reilly MS, Boehm T, Shing Y, Fukai N, Vasios G, Lane WS, Flynn E, Birkhead JR, Olsen BR, Folkmann J: Endostatin: an endogenous inhibitor of angiogenesis and tumor growth. Cell 2007, 88:277-285.

8. Roberts DD: Thrombospondins: from structure to theapeutics. Cell Mol Life Sci 2008, 65:669-67I.

9. Nyberg $P, X i e$ L, Kalluri R: Endogenous inhibitors of angiogenesis. Cancer Res 2005, 65:3967-3979.

10. Takahashi $H$, Shibuya $M$ : The vascular endothelial growth factor VEGF/VEGF receptor system and its role under physiological and pathological conditions. Clin Sci (Lond) 2005, 109:227-224.

II. Presta M, Dell'Era P, Mitola S, Moroni E, Ronca R, Rusnati M: Fibroblast growth factor/fibroblast growth factor receptor system in angiogenesis. Cytokine and Growth Factor Reviews 2005, 16:159-178.

12. Nagy JA, Dvorak AM, Dvorak HF: EGF-A(164/165) and PIGF: roles in angiogenesis and arteriogenesis. Trends in Cardiovasc Med 2003, 13:169-175.

13. Fotsis J, Pepper M, Adlercreutz H, Fleischmann G, Hase T, Montesano $\mathrm{R}$, Schweigerer L: Genistein, a dietary-derived inhibitor of in vitro angiogenesis. Proc Natl Acad Sci (Wash) 1993, 90:2690-2694.

14. Kobayashi S, Miyamoto T, Kimura I, Kimura M: Inhibitory effect of isoliquitrin, a compound in licorice root, on angiogenesis in vivo and tube formation in vitro. Biol Pharm Bull 1995, 18:1382-1386.

15. Sato K, Mochizuki M, Saiki I, Yoo YC, Samukawa K, Azuma I: Inhibition of tumor angiogenesis and metastasis by a saponin of Panax ginseng, ginsenoside-Rb2. Biol Pharm Bull 1994, 17:635-639.

16. Kim MS, Lee YM, Moon E-J, Kim SE, Lee JJ, Kim K-W: Anti-angiogenic activity of torilin, a sesquiterpene comp;ound isolated from Torilis Japonica. Int J Cancer 2000, 87:269-275.

17. Atta-ur-Rahman, Naz H, Makhmoor T, Yasin A, Fatima N, Ngounou FN, Kimbu SF, Sondengam BL, Choudhary MI: Bioactive constituents from Boswellia papyrifera. J Nat Prod 2005, 68: I89-193.
18. Hussain S, Slevin M, Matou S, Ahmed N, Choudhary M, Ranjit R, West $D$, Gaffney J: Anti-angiogenic activity of sesterterpenes; natural product inhibitors of FGF-2 induced angiogenesis. Angiogenesis 2008, II:245-256.

19. Hussain S, Slevin M, Mesaik M, Elosta M, Matou S, Ahmed N, West D, Gaffney J: Cheiradone: a vascular endothelial cell growth factor antagonist. BMC Cell Biol 2008, 9:7.

20. Kimura $Y$, Okuda $\mathrm{H}$ : Effects of naturally occurring stilbene glucosides from medicinal plants and wine on tumour growth and lung metastasis in Lewis lung carcinoma-bearing mice. J Pharm Pharmacol 2000, 52:1287-1295.

21. Hwang JT, Kwak DW, Lin SK, Kim HM, Kim YM, Park OJ: Reservatol induces apoptosis via modulation of AMPK signalling. Ann N Y Acad Sci 2007, 1095:44I-448.

22. Zhang YZ, Shen JF, Xu JY, Xiao JH, Wang JL: Inhibitory effects of 2,3,5,4'-tetrahydoxystilbene-2-O-beta-D-glucoside on experimental inflammation and cyclooxegenase 2 activity. J Asian Nat Prod Res 2007, 9:355-363.

23. Ghajar CM, George SC, Putnam AJ: Matrix metalloproteinases control of capillary morphogenesis. Crit Rev Eukaryot Gene Expr 2008, 18:25I-278.

24. van Hinsbergh VW, Koolwijk P: Endothelial sprouting and angiogenesis: matrix metalloproteinases in the lead. Cardiovasc Res 2008, 78:203-2I2.

25. Yu F, Kamada H, Niizuma K, Endo H, Chan PH: Induction of MMP9 and endothelial injury by oxidative stress after spinal cord injury. J Neurotrauma 2008, 25: 184-195.

26. Slevin MA, Krupinski J, Slowik A, Rubio F, Szczudlik A, Gaffney J: Activation of MAP kinase (ERK-1/ERK-2), tyrosine kinase and VEGF in the human brain following acutr ischaemic stroke. Neuroreport 2000, I I:2759-2764.

27. Li XJ, Yue PY, Ha WY, Wong DY, Tim MM, Wang PX, Wong RN, Liu $L$ : Effect of sinomenine on gene expression of the II-I betaactivated human synovial sarcoma. Life Sci 2006, 79:665-673.

28. Duraisamy Y, Slevin M, Smith N, Bailey J, Zweit J, Smith C, Ahmed N: Effect of glycation on basic fibroblast growth factor induced angiogenesis and activation of associated signal transduction pathways in vascular endothelial cells; possible relevance to wound healing in diabetes. Angiogenesis 200I, 4:277-288.

29. Slevin M, Kumar S, Gaffney J: Angiogenic oligosaccharides of hyaluronan induce multiple signalling pathways affecting vascular endothelial cell mitogenic and wound healing responses. J Biol Chem 2002, 277:4I 046-4I059.

30. Ifat S, Tamer L, Lubinsky-Mink S, Kuhn J, Adir N, Chaterejee S, Schomburg D, Ron D, Mink S, Noam A, Shivani C, Dietmar S, Dina R: Identification of residues important for primary receptor binding and specificity in fibroblast growth factor 7 . $J$ Biol Chem 2000, 275:3488I-34886.

31. West DC, Thompson WD, Sells PG, Burbridge MF: Angiogenesis assays using the chick chorioallantoic membrane. In Methods in molecular Medicine-angiogenesis: reviews and protocols Edited by: Murray JC. Humana Press; 2001: 107-130.

32. Daunes S, D'Silva C: QSAR study on the contribution of log $\mathbf{P}$ and Es to the in vitro antiprotozoal activity of glutathione derivatives. J Med Chem 2001, 44:2976-2983.

Publish with Bio Med Central and every scientist can read your work free of charge

"BioMed Central will be the most significant development for disseminating the results of biomedical research in our lifetime. "

Sir Paul Nurse, Cancer Research UK

Your research papers will be:

- available free of charge to the entire biomedical community

- peer reviewed and published immediately upon acceptance

- cited in PubMed and archived on PubMed Central

- yours - you keep the copyright 